\title{
NAAS Reports
}

\section{The 1979 NAAS Conference at Hanasaari, Espoo, Finland.}

The seventh triennial Conference of the Nordic Association for American Studies was arranged at the Swedish-Finnish Cultural Center just outside Helsinki on June 14-17, 1979.

The Conference was planned and arranged by a Finnish Conference Committee with Professor Nils Erik Enkvist as Chairman. The other members of the Conference Committee were Mr. Jerker A. Eriksson (vice-chairman), Mr. Markku Henriksson, Dr. Olavi Koivukangas, Prof. Matti Rissanen, Prof. Kari Sajavaara and Mrs. Marja Wuorenheimo. The Secretary of the Conference Committee was Dr. Tuomo Laitinen, Secretary of NAAS.

The conference was fairly equally financed by the United States International Communication Agency and the Finnish Ministry of Education, with the Nordic ICA Posts and Ministries of Education contributing toward the travel expenses of the participants.

The participants came from 10 countries, and 127 participants were officially registered: 56 from Finland, 21 from Norway, 18 from Sweden, and 16 from Denmark. Guests, speakers, and commentators from other countries make up the rest.

The speakers at the Opening Ceremony were Mr. Kalevi Kivistö The Finnish Minister for Education, Miss Rozanne L. Ridgway, the United States Ambassador to Finland, and the Association's Chairman, Professor Per Seyersted.

The overall theme of the conference was "Confrontation and Adjustment in American Culture." A brief report will be given below of all the papers.

In the first paper of the conference, "Toward a Cultural Approach to American Studies." Mr. Fredrik Brøgger argued that the concept of culture might be helpful in American studies, and claiming that cultural patterns equal national character he suggested that cultural study can become a discipline in its own right and contribute significantly to the study of language and literature in the English departments. Prof. Luther Luedtke (University of California) expressed his admiration for a sophisticated explanation of the usefulness of cultural anthropology in resolving the conflict between humanistic studies and sociology in American studies but questioned the need for such a resolution.

In his paper entitled "Confrontation with 'the Machine' in American Literature and Life", Professor Leo Marx (MIT) advanced the view of the pseudo-left or counterculture movement as essentially pastoral in nature, and established structural and ideological similarities between the responses to social change in recent years and the response to industrialization in American literature in the 1840 's. In his commentary on the above, Prof. Robert Crunden (University of Texas at Austin) opposed Prof. Marx's use of the machine metaphor and con- 
cluded that this was a misrepresentation of the Americans' attitude toward their machines and that the metaphor thus did not work.

Professor Ursula Brumm (Free University, Berlin) pursued the theme of confrontation and adjustment in literature in her paper entitled "History and Wilderness; Some Reflections on the Use of the Past in American Literature." She traced the development of the Americans' attitude to nature from colonial American inability to understand and celebrate nature to later initiation into and subsequent destruction of the wilderness. The commentator, Prof. Orm Øverland pointed out that the Indians had a civilization of their own and, further, disagreed with the speaker's use of material for her analysis of the Puritan period on the one hand and of the Romantics on the other.

Professor John G. Cawelti (University of Chicago) discussed in his paper "Ethnic Experience and Popular Culture" the special characteristics of American popular culture that helped to shape ethnic involvement in it. He also commented on the recent changes in the treatment of race and ethnicity in popular culture, pointing out how there has been a movement toward more positive and sympathetic treatment of ethnic life in America. Commenting on this paper, Mr. Jerker A. Eriksson (University of Helsinki) stressed the importance of the moving picture as the first and most important encounter with American culture, admitting however that the movies did not directly concern themselves with the lot of the immigrant.

Prof. J. Donald Wilson (University of British Columbia) in "Patterns of Assimilation" concluded that the impulse towards conformity in the United States had created the melting-pot metaphor while Canada's heterogeous society had given rise to the mosaic concept. Dr. Harald Runblom (University of Uppsala) disagreed with the conclusion wanting rather to stress the similarities between the Canadian and the United States situations.

Prof. Allan Winkler (Yale University) in his paper "On the Civil Rights Movement Since World War II' argued that the seeds of the movement were planted during the war and then traced the development of the movement up to early 1970's.

Prof. Per Seyersted (University of Oslo) discussed in his paper "American Indian Literature" the different kinds of early Indian literature and the modern writers who make use of Indian literary traditions. He concluded that white writers cannot write as convincingly about the Indian as the Indians themselves and expressed a hope for native American writers to appear on the literary scene to give expression to the native American experience. Prof. Olov Fryckstedt (University of Uppsala) in "Immigration and American Literature" discussed the reasons why there has been very little literature concerning the immigrant experience and concluded that the topic apparently was too controversial due to an antagonism felt towards the immigrants. Dr. Helge Norrman Nilsen (University of Trondheim) in response to the above rather wanted to stress the importance of prejudice as a hindering factor.

Dr. Henrik Rosenmeier (University of Copenhagen) in his lecture on American poetry attempted to demonstrate a continuity in twentieth century American poetry based on a realist use and consideration of natural phenomena. Mme Jacqueline Morin (of Lyon, France) reported on an extensive and sophisticated cinema club program run in Lyon by M. Jacques Morin for the benefit of those students who want to learn about America as well and not just watch movies. 
Prof. Kari Sajavaara (University of Jyvaskyla) introduced a research program on American influence on local cultures and discussed American studies at Secondary level in Finland. His paper was complemented by contributions by Ole Bom (Denmark), Fredrik Brøgger and Alf Bårdtvedt (Norway), and Airi Riisalo and Matti J. Castrén (Finland)

The conference program also included workshops that

- continued the discussions around the themes and ideas introduced by Professors Cawelti and Marx

- continued the discussion on American Studies in Scandinavian High Schools,

- introduced the topic of American studies at Hungarian universities (Dr.

Laszlo Bordanyi)

- discussed migration studies and

- introduced the American History Project (by Prof. Lewis Hanke).

In a concluding panel discussion chaired by Professor Pertti Pesonen (University of Helsinki), Prof. Marx defended his view that the machine that the students at Berkeley and elsewhere thought they were fighting was simply a metaphor for the whole socio-economic system.

He also discussed the efforts at MIT to mitigate the conflict between the Humanities and Technology by giving technology students a more humanistic education. He further stressed the profit motive as a source and inspiration for new technology and wanted to view it against the need, for instance, of better housing for the blacks.

Professor Sten Carlsson (Uppsala University) first recalled that American culture is in essence, European civilization, but he also noted that American have demonstrated that their civilization is a whole. He further stated that technological development now is so fast that human aspects are being neglected.

Dr. Torbjørn Sirevåg (Ministry of Education, Oslo) stressed the global (as opposed to merely American) confrontation with technology. He further suggested that the term 'salad bowl' might be more appropriate as far as the American society is concerned. .

Professor Lewis Hanke (University of Massachusetts, Amherst) also wanted to discard the melting-pot mataphor considering it rather a superficial one. And introducing a new aspect he talked about those in the American society who did not want to accommodate, such as the Southerners who, after the Civil War, went to Brazil to live there as well as the mormons, who also have had trouble accommodating into the American society.

The General Meeting of the Association was held on the second day. The meeting heard reports by the Chairman, Prof. Per Seyersted, and the Editor of American Studies in Scandinavia, Prof. Orm Overland, and accepted the constitution of the European Association for American Studies, thus making it possible for the NAAS to remain a member in that body. The meeting further adopted $\boldsymbol{a}$ new constitution for the Nordic Association itself, establishing among other things, National Sub-Committees with a right to arrange programs, meetings and seminars in each individual country. The ordinary members of the NAAS Executive Board will act as chairmen of the subcommittees in each country. It was decided to hold the next triennial meeting in Denmark in 1982 and the Danish National Subcommittee was given the task of arranging the conference. 
For 1979-1982 the Executive Board Members are:

Chairman : Dr. Tuomo Laitinen, University of Tampere,

Members: Dr. Henrik Rasenmeier, University of Copenhagen

Mr. Fredrik Chr. Brøgger, University of Tromsø

Prof. Olov Fryckstedt, University of Uppsala

Deputy Members (and simultaneously, members of the National Subcommittees) :

Finland: Mr. Jerker A. Eriksson, University of Helsinki

Prof. Reino Erma, University of Tampere

Mr. Markku Henriksson, University of Helsinki

Ms. Marja Wuorenheimo, Helsinki

Norway: Ms. Ingeborg Aasnaes, Oslo

Dr. Robert Baehr, Grimstad

Sweden: Dr. Rolf Lundén, University of Uppsala

Prof. Göran Rystad, University of Lund

At the first meeting of the new Executive Board, Dr. Henrik Rosenmeier was elected Vice-chairman and Mr. Markku Henriksson Secretary of the Association.

Tuomo Laitinen

The NAAS and American Studies in Secondary Schools

"American Studies In The Classroom" was the title of a conference held by the British Association for American Studies at Digby Stuart College, London, Prom March 31 to April 4, 1980. In terms of both structure and content, this conference represents a manner of promoting and aiding the teaching of American Studies in secondary schools that our own association can learn much from. In the following article I will review the reasons for this and put forward suggestions as to how we can improve the quality and quantity of American Studies in our secondary schools.

In arranging this conference the BAAS used a "two tier" system. By this I mean that the national organization held two conferences; one designed for those teaching and researching on the undergraduate and graduate level (held some days earlier) and one at Digby Stuart focusing on teaching at the secondary school and undergraduate level. Thus the title '(American Studies In the Classroom." This was done in recognition of the fact that the teaching of American Studies on this level merits consideration on its own part; that it poses its own problems both in terms of material and techniques, rather than being viewed as a $n$ appendage to more advanced studies.

The point here was not so much that the teaching of American Studies at the university and secondary school levels were considered to be two separate areas, but rather that the challenges facing teachers of American Studies were equally, as difficult and demanding as those facing university and college researchers. It was a way, as one delegate put it, of ridding secondary school teachers in particular of the status of "second class citizens" within their own organization. Thus rather than separating these two levels of education, the conference in London was designed to span the gulf that too often exists between them. 
This became evident in the manner in which the actual work of the conference took place. Themes were choosen with an eye to providing concrete examples of work done in the classroom at both levels. Among these were Immigration, The City, Regionalism/Sectionalism, The West, Science and Technology, and the Search for Equality. Workshops were structured so as to pool resources. Within most, the conference provided a team of teachers from a secondary school and a university, respectively. In addition, participants in the workshops spanned both levels of education. This gave the workshops a function different to that usually assigned them. Rather than being designed to create a general interest in American Studies among secondary school teachers or as "spot courses" to bring teachers up to date on the latest research, these workshops concentrated in large part on comparing the two levels of teaching in terms of goals set, methods used, material provided and results expected.

This was extremely profitable for all concerned. Rather than filtering down to secondary school teachers individually, information was circulated in an open forum allowing both sides to understand the others' requirements and offer useful suggestions. Not surprisingly, both groups of teachers found that they had much in common. Differences were of degree, rather than substance.

Can this way of conducting a conference be adapted to our needs in the Nordic countries? Well, obviously there are important differences between us and BAAS. First of all, we are teaching American Studies as part of a foreign language cirriculum. This limits us, particularly on the secondary school level, and differentiates us more sharply between levels. Secondly, we do not have as much time as our British counterparts to teach American Studies; up to six hours a week over one or more years. Thirdly, to my knowledge there is no generally accepted or institutionally stipulated set of materials or requirements defining the teaching of American Studies in secondary schools in Norway or among the Nordic countries. Such requirements exist in Great Britian for an 0-level and A/O-level syllabus for American Studies. Finally, lack of sufficient teacher training and of access to ordered and suitable materials for teaching American Studies has tended to scare off many secondary school teachers who might otherwise have been interested in our discipline. The American Studies program is better developed in Britian and, as a consequence, there are simply more of them than of us in the Nordic countries.

Having said this much and listed our woes, I would nonetheless suggest that there is much we can learn and adapt from our British colleagues. Precisely because teaching American Studies has been centered by and large at our universities and colleges, it is important for the promotion of these studies that there be regular contact between these and our secondary schools. The BAAS conference in London offers an excellent example of how to establish such contact. Moreover, in this form such contact would be to the benefit of both parts. The gap which has existed between these levels of education has been detrimental for both. Without the one, the other must inevitably suffer some degree of isolation. If this point is accepted, the next question to be asked is on what basis such contact should be started; that is, given the level of American Studies in the secondary schools, exactly what should we get together to talk about?

There are many possible areas of interest. As I view it, the most pressing need among teachers of American Studies in secondary schools is for an integrated set of materials of suitable language level and content to help balance an otherwise 
often sketchy knowledge of the discipline and a set of even vaguer institutional requirements. Since the NAAS conference in Helsinki in 1979, I have been engaged in collecting materials for such an "American package." This has been an uphill climb. Unlike Britain, the United States has not been particularly active in fostering study of its language as such. Most material relevant to the teaching of American Studies is beyond the linguistic reach of secondary school pupils. This has left those of us interested in teaching American Studies as part of our basic or advanced English courses at the mercy of scattered texts, films, TV programs, etc.; the "snapshot" variety of teaching cultural background.

Here again the BAAS conference can give us some helpful hints as to how to better the situation. One of the strengths of the conference was its inclusion of delegates from all over the Continent. Here they face many of the same problems as we do, particularly the teaching of American Studies as part of a foreign language curriculum. Over the past years several groups in Germany have been active in gathering and editing material to create an American package like that I've outlined above. In London, one afternoon session was devoted to a review of their progress and a discussion of their problems. Professor Peter Freese, working in collaboration with Professor Erwin Helms, heads a group presently working on a series of volumes plus a teachers' book (which Professor Helms deplores) called the T.E.A.S. series; "Texts for English and American Studies." So far, seven titles have been published. Another two will be appearing soon. Further titles are planned, but publication will not take place until 1981. Though these may be somewhat advanced for our secondary school pupils, they should prove quite useful. They have been tested in the classroom and revised by a team of researchers and practicing teachers. They are published by Verlag Ferdinand Schoningh, Juhenplatz am Rathaus, 4790 Paderborn, W. Germany.

There are two useful lessons to be learned here. First, that it would be worth our while to strengthen our ties with our fellow teachers on the Continent, inviting them to our conferences to exchange valuable experience. Second, that we should be more active both as an organization and individually within our respective educational systems in creating similar groups to work with American Studies in the secondary schools. Professor Peter Funke made the point quite well when he said in his summation that we must now realize that developing suitable materials and techniques for teaching American Studies is in itself a vital branch of research in our discipline.

To sum up, I would suggest that the NAAS apply the two tier system reviewed here. Though it is probably not within our capacity to host two separate conferences at this time, we can certainly organize workshops over several days specifically dealing with classroom situations. These could be prepared by correspondence or prior meetings. One possible subject for discussion in these workshops might be the requirements of an integrated set of materials or package. This could be done either in terms of separate themes already developed by teachers or in terms of general needs and research targets - or both. The materials of our German colleagues could be a useful point of departure for this. Certainly - and as my final suggestion - I would recommend that delegates interested in this field of research be invited from sister organizations in Europe.

In conclusion, there is a general recognition within the NAAS of the need to promote and aid American Studies in the secondary schools. Though we will probably never rival the influence of British culture and society on the teaching 
of English, for reasons of geography as well as tradition, our ties with the United States are expanding as the world shrinks technologically. This, accordingly, increases the need and desire for understanding of the United States on all levels of education. One British delegate in London went so far as to say, "The future of American Studies lies far more in the classroom than in graduate studies programs." If that is an exaggeration, certainly the future of American Studies in the secondary schools deserves careful thought, planning and cooperation. This will promote and aid the teaching of American Studies on all levels.

Robert Miklkelsen 